\title{
PENCEGAHAN TINDAK PLAGIARISME DALAM PENULISAN SKRIPSI: UPAYA MEMPERKUAT PEMBENTUKAN KARAKTER DI DUNIA AKADEMIK
}

\author{
Mulyana \\ FBS Universitas Negeri Yogyakarta (e-mail: mul mj@yahoo.com; HP 081328817165)
}

\begin{abstract}
Plagiarism Prevention in Thesis Writing: An Attempt to Strengthen Character Building in the Academic World. The study is aimed at describing plagiarism in thesis writing at a tertiary educational institution. The study was conducted in the Javanese Department, Faculty of Language and Arts, Yogyakarta State University. The data were collected through in-depth interviews and observations, and analysed using the explanatory approach, espesially the qualitative descriptive technique. The findings show that plagiarism in thesis writing includes duplicating, consisting of (1) duplicating titles, (2) duplicating contents, (3) duplicating theories, (4) duplicating, and (5) duplicating references. The process approach in thesis writing can be used to prevent plagiarism. Such an approach consists of steps as follows: returning the thesis draft, showing original sources, and cancelling the thesis. These can be carried out by investigating, discussing, evaluating, and presenting thesis titles and contents.
\end{abstract}

Keywords: plagiarism, thesis writing, character building

\section{PENDAHULUAN}

Salah satu nilai tertinggi karya tulis adalah orisinalitas atau keaslian. Pernyataan ini mengandung makna, bahwa sebuah karya tulis harus memiliki nilai kualitas dalam hal keaslian, objektivitas, dan kejujuran. Makna 'asli' bukan berarti semua ide, gagasan, dan pengetahuan yang disampaikan seseorang dalam karya tulisnya tersebut, semuanya berasal dari dirinya sendiri. Melainkan lebih pada kejujuran dalam mengemukakan tulisannya. Apabila sebuah kata, kalimat, paragraf, ide, gagasan, atau pendapat yang dimunculkan dalam tulisanya tersebut adalah milik orang lain (atau dari sumber lain), maka etika ilmiahnya adalah: mencantumkan sumber dengan jujur dan objektif di mana ia mendapatkan kutipan tersebut. Kasus-kasus duplikasi, penjiplakan, atau plagiarisme muncul, justru karena nilai kejujuran dan objektivitas ini dilanggar atau diabaikan.

Dalam dunia akademik, terutama di perguruan tinggi, seluruh warga civitas akademika (khususnya dosen dan mahasiswa) diharapkan memegang teguh etika akademik yang berlaku. Kejujuran atau orisinalitas ilmiah dalam hal karya tulis termasuk dalam bingkai character building. Artinya, warga civitas akademika seharusnya selalu menjaga semangat mengembangkan nilai dan wa- 
tak kejujuran dalam aktivitas ilmiahnya (Ismail. 2007:4). Apabila nilai ini hilang, atau luntur, maka serta merta kualitas kemanusiaan - terutama di lingkungan akademik - juga mengalami keruntuhan. Bahkan, Menteri Pendidikan Nasional, Muhammad Nuh menyebut, "maraknya tindak plagiarisme menunjukkan lemahnya pendidikan karakter, budaya, dan moral insan di dunia akademik" (Rachmad, 2010:15).

Watak dan sikap yang termuat dalam butir etika akademik-ilmiah yang harus dijunjung tinggi adalah jujur dan objektif dalam kehidupan ilmiah (Etika Mahasiswa dan Dosen UNY, 2005). Salah satu kegiatan atau aktivitas terkait dengan nilai kejujuran dalam kehidupan ilmiah adalah: sikap dalam penulisan karya tulis. Dalam konteks penulisan dan penelitian ini, karya tulis yang langsung terkait dengan mahasiswa adalah Tugas Akhir Skripsi (TAS). Karya tulis inilah yang perlu mendapat tekanan dan perhatian serius. Persoalan ini sangat signifikan dikelola dan diteliti terkait dengan banyaknya gejala plagiarisme yang terjadi di dalamnya. Mahasiswa UNY untuk sebagian besar disiapkan sebagai calon pendidik, dan calon ilmuwan. Oleh karena itu, kemampuan menulis karya ilmiah harus ditegakkan seiring dengan tuntutan profesionalise guru (Suyanto, 2007:2).

TAS dapat dianggap sebagai karya tulis mahasiswa yang paling besar porsinya secara ilmiah. Penyelesaiannya membutuhkan sejumlah kemampuan, energi, pemikiran, tenaga, bahkan dana yang relatif banyak. Oleh karena itu, TAS sering menjadi kebanggaan maha- siswa karena dianggap paling berbobot. Penyelesaian tugas akhir ini sering menjadi pertaruhan studi mahasiswa. Banyak mahasiswa yang gugur/DO (droup out), atau terpaksa alih jenjang karena gagal menyelesaikan tugas akhir ini. Sebaliknya, bagi mahasiswa yang mampu menyelesaikan tugas skhir (skripsi) sesuai tepat waktu, atau apalagi, kurang dari waktu yang telah ditentukan (artinya selesai lebih cepat), dan berkualitas, akan menjadi kenangan dan kebanggaan yang tidak mudah terlupakan begitu saja. Banyak pihak, misalnya jurusan, dosen PA, dosen pembimbing, dosen penguji, orang tua, keluarga, teman-teman, akan memuji dan membanggakanya.

Sesuai dengan buku Panduan Tugas Akhir yang diterbitkan oleh FBS UNY (PTA, 2006), sebuah karya tulis penelitian bentuk skripsi, diformatkan mencantumkan relevansi dengan karya penelitian orang lain terdahulu. Namun, sudah menjadi rahasia umum, bahwa cara ini justru menggiring mahasiswa untuk melakukan duplikasi atau plagiarisme. Sadar atau tidak, cara mengutip yang dilakukan telah mendekatkan karya tulis mereka pada karya tulis orang lain. Dari sinilah antara lain gejala plagiarisme muncul. Plagiarisme, atau jiplakan (Moeliono, ed. KBBI, 1988: 690) adalah pengambilan karya orang lain, dan dipublikasikan sebagai karya miliknya. Senyatanya, terutama di dunia ilmiah, pengambilan tulisan atau mengutip karya orang lain tersebut, kadang-kadang justru dianjurkan namun dengan aturan dan norma yang telah berlaku dan disepakati secara luas di dunia akademik. Persoalannya, se- 
berapa besar kadar pengambilan kutipan, bagaimana cara mengutip, dan apakah pihak pengutip menyertakan sumber kutipannya atau tidak; adalah sesuatu yang musykil dan sulit ditelusur. Sementara itu, aksi plagiarisme terus berjalan, tidak ada peraturan yang mampu menghentikannya. Buktinya, gejala ini sampai sekarang terus terjadi. Tindak-tindak plagiarisme karya tulis ilmiah satu persatu bermunculan dan terpublikasi secara luas, yang menyebabkan tercorengnya nilai kejujuran dan objektivitas pelaku pendidikan (terutama) di perguruan tinggi.

Keberadaan aturan, etika, atau panduan penulisan tugas akhir skripsi, tesis, atau disertasi di PT tampaknya bukan jaminan untuk menghentikan perbuatan jiplak-menjiplak ini. Berkalikali dunia kampus digegerkan oleh ulah oknum mahasiswa atau dosen yang mempublikasikan karya tulis penelitiannya, yang akhirnya terbukti karya tersebut hasil plagiarisme. Sebagai contoh, kasus yang terjadi di salah satu PT terkemuka di Yogyakarta, seorang promovendus (kandidat doktor), terpaksa dibatalkan gelar doktornya oleh pihak Senat Universitas, setelah terbukti dengan sah, bahwa karyanya sebagian besar adalah hasil plagiarisme (KR, 12/04/2005). Pada kesempatan yang sama dia juga dilarang tampil dalam berbagai kesempatan presentasi ilmiah dan sejumlah penelitian. Pada awal tahun ini, di Bandung terdengar berita menghenyakkan dunia akademik, seorang guru besar terbukti melakukan penjiplakan dengan melakukan aksi mempublikasikan tulisan artikel di The Jakarta Post, yang akhirnya ternyata hanya "copy paste" dari tulisan orang lain di sebuah jurnal. Terakhir, seorang doktor lulusan ITB juga terindikasi melakukan tindak plagiarisme ketika mempresentasikan papernya di forum internasional, yang akhirnya terbukti bahwa karyanya tersebut hasil plagiasi sewaktu masih studi S3 (http://edukasi.kompas.com/read/2010/10/15; Running News TVONE, 18/04/2010). Fakta dan fenomena ini benar-benar memprihatinkan. Sebagian orang bahkan menyebut plagiarisme adalah tragedi moral di dunia akademik.

Plagiarisme karya tulis, secara formal, termasuk perbuatan melawa hukum. Gejala yang terjadi adalah tindak pidana pencurian atas hak kepemilikan yang dimiliki oleh orang lain. Apabila sang pemilik hak mengetahui bahwa karya ciptanya dicuri, dan dirinya tidak bisa menerima perbuatan tersebut maka secara hukum kasus ini dapat dipidanakan. Orang yang mencuri, menjiplak karya orang lain dapat dikenai hukuman sesuai dengan keputusan hukum yang adil; misalnya, sanksi administrasi, didenda, dicabut karyanya, dibatalkan gelarnya, atau dipenjara. Berkembangnya tindak-tindak plagiarisme - terutama di PT - harus secepatnya diantisipasi karena bertentangan dengan semangat pengembangan watak atau karakter (character development) civitas akademika di dunia pendidikan (Astin, 1993:5).

Memang, sejumlah persoalan terminologis muncul seiring dengan pemahaman 'plagiarisme' karya tulis ilmiah. Misalnya, bagaimana mengukur atau menyebut bahwa tulisan seseorang dikatakan menjiplak tulisan orang lain. 
Apa saja indikator yang dapat digunakan untuk mendefinisikan dengan tepat bahwa seseorang telah melakukan perbuatan melawan hukum yang disebut plagiarisme. Seberapa banyak (berapa prosentasenya) seseorang boleh melakukan pengutipan dari sumber lain. Padahal, kenyataanya, karya tulis baru disebut "ilmiah" justru apabila ada kutipan pendapat orang lain. Menuliskan sumber berarti, mengidentifikasi pencipta suatu ciptaan yang kita gunakan sebagai sumber kutipan kita: judul ciptaan, nama pencipta, penerbit, dan sebagainya, harus dengan jelas diungkapkan dengan cara yang sesuai dengan bentuk dari perbanyakan atau eksploitasi (ACCU dan IKAPI, 2006; Panduan HKI, 2006:34). Barangkali cara ini dianggap tepat dan ampuh menjadi "pagar penjaga" terjadinya tindak-tindak plagiarisme dalam penulisan karya tugas akhir mahasiswa di lingkungan akademiknya.

Berdasarkan catatan, kasus-kasus plagiarisme di dunia pendidikan (termasuk di perguruan tinggi), terjadi karena lemahnya aturan, dan kurangnya kesadaran moral ilmiah seorang penulis. Jadi, salah satu indikator utama terjadinya plagiarisme adalah pengambilan kutipan (entah sedikit atau banyak), tetapi si pengutip "tidak menyebutkan sumber kutipannya". Sehingga seolah-olah apa yang ditulisnya adalah miliknya sendiri. Bunyi aturan formal yang dilansir FBS UNY adalah "pengambilan dan cara mengutip (data, pendapat, hasil penelitian) orang lain atau pustaka yang bukan karangannya sendiri, wajib menyertakan sumber asli kutipannya" (Panduan TAS/TABS FBS, 2006:3). “Me- nyertakan sumber asli" berarti pengutip harus mengidentifikasi secara eksplisit sumber tulisan: nama penulis/ pencipta, penerbit, tahun terbit/publikasi, halaman, dan seterusnya.

Sebenarnya, secara formal, mahasiswa diwajibkan menulis di halaman pernyataan bahwa apa yang ditulisnya adalah benar-benar karya sendiri. Setelah menuliskan identitas dirinya secara jelas penulis tugas akhir harus menyatakan ungkapan formal sebagai berikut.

"Menyatakan bahwa karya ilmiah ini adalah hasil pekerjaan saya sendiri. Sepanjang pengetahuan saya, karya ilmiah ini tidak berisi materi yang ditulis oleh orang lain, kecuali bagian-bagian tertentu yang saya ambil sebagai acuan dengan mengikuti tatacara dan etika penulisan karya ilmiah yang lazim. Apabila ternyata terbukti bahwa pernyataan ini tidak benar, sepenuhnya menjadi tanggungjawab saya."(PTA, Lampiran, 2006:38).

Persoalannya, apakah tulisan pernyataan tersebut mampu menjaga kejujuran mahasiswa? Mampukah pernyataan itu menjamin tidak terjadinya gejala plagiarisme dalam penulisan tugas akhir? Bagaimana sebenarnya bentuk-bentuk plagiarisme skripsi ini bisa terjadi? Inilah sejumlah persoalan yang akan dikaji dalam penelitian ini. Hasil akhir yang diharapkan dari upaya ini antara lain adalah terciptanya budaya penulisan karya ilmiah mahasiswa yang objektif, orisinil, dan bertanggungjawab. Pada gilirannya, apabila pola ini tercipta dan terkondisi, 
maka bukan tidak mungkin jenis-jenis penelitian mahasiswa akan semakin berkualitas dan bervariasi. Usaha ke arah pembenahan diri (self-renewal) perlu diaplikasikan (Suyata, 1998:3). Salah satu cara aplikatif dan efektif yang dapat mengurangi plagiarisme dalam penulisan Tugas akhir adalah dengan menerapkan 'pendekatan proses' secara jelas, mantap, dan berkelanjutan.

Pendekatan proses (PP) atau yang sering disebut pendekatan keterampilan proses (PKP) adalah seluruh irama dan tindakan dalam proses belajar mengajar yang dapat menciptakan kondisi belajar siswa aktif. PP ini disandarkan juga pada pengolahan penelitian Sudaryanto (2000) dengan penyesuaian tertentu dengan tujuan mengantisipasi adanya gejala plagiarisme atau duplikasi karya skripsi mahasiswa. Penjabaran dan tahapan PP tersebut adalah sebagai berikut: (1) pramenulis (tahap ini mahasiswa diberi tugas mencari topik skripsi, menyusun kerangka karangan, mencari bahan-bahan acuan, dan menyiapkan segala sesuatu yang dapat menunjang kerja ilmiah tersebut); (2) penyusunan draf (tahap ini mahasiswa harus sudah selesai menyiapkan dan menyusun draf sementara untuk proposal tugas akhir; (3) revisi (tahap perbaikan dan pembenahan draf setelah dikoreksi oleh dosen pembimbing dan mahasiswa lain (sebagai koreksi silang dan antisipasi gejala plagiarisme); (4) editing (tahap penyuntingan dilakukan dengan cara membenahi draf yang telah dikoreksi; dan (5) sharing (tahap berbagi adalah langkah publikasi terbatas yang dilakukan tim skripsi untuk menyebarluaskan draf yang telah diajukan mahasiwa kepada lingkup terbatas (komunitas dosen, dan kelas mahasiswa) untuk dibaca, dikoreksi, dan didiskusikan.

\section{HAK CIPTA KARANGAN ILMIAH}

Hak cipta karangan ilmiah termasuk dalam bingkai HAKI (Hak atas Kekayaan Intelektual) atau HKI (Hak Kekayaan Intelektual). Istilah ini merupakan terjemahan dari "Intellectual Property Right" (IPR). Kata kuncinya adalah "hak", "kekayaan", dan "intelektual". Kekayaan merupakan abstraksi yang dapat dimiliki, dialihkan, dibeli, maupun dijual. Sedangkan "kekayaan intelektual" merupakan kekayaan atas segala hasil produksi kecerdasan daya pikir, seperti teknologi, pengetahuan, seni, sastra, gubahan lagu, karya tulis, karikatur, dan sebagainya (Pengenalan HAKI, Sentra HAKI, Lemlit UNY, 2008:3).

HKI dalam pengertian yang luas adalah hak-hak yang diberikan untuk melindungi nilai ekonomi bagi usahausaha kreatif. Jenis-jenis usaha kreatif meliputi hak Paten (patens), hak cipta (copy rights), hak merek (trademarks), desain industri (industrial designs), rahasia dagang (trade secrets), indikasi geografis (geographical indications), desain tata letak sirkuit terpadu (layout design of intregrated circuits) dan perlindungan varietas tanaman (plant variety protection).

Nilai penghargaan dan perlindungan HKI tidak saja bermakna mematenkan. Salah kaprah yang terjadi selama ini adalah misalnya, untuk melindungi suatu lagu, dikatakan mematenkan lagu, melindungi merek, dikata- 
kan mematenkan merek, melindungi suatu disain dikatakan mematenkan desain. Kata "paten" hanya tepat digunakan jika kita ingin mendaftarkan invensi penemuan kita ke Negara (Sentra HKI Lemlit, 2008:4). Hak paten yang telah diperoleh sekaligus harus menjadi alat perlindungan bagi karyanya.

Etika menulis karangan ilmiah sebenarnya masuk dalam ranah moral akademis. Oleh karena itu, aturannya sering hanya bersifat formalitas saja. Sebut saja misalnya, pada setiap karangan ilmiah TAS/TABS wajib disertakan halaman pernyataan yang isinya menyatakan bahwa, karya ilmiah yang ditulisnya adalah benar-benar karya sendiri dan bukan hasil jiplakan karya orang lain (Panduan TAS, 2006:3). Semangat yang melandasi pernyataan ini adalah menjunjung tinggi nilai kejujuran dan orisinalitas sebuah karya tulis yang menjadi hak milik seseorang. Sudut pandangnya bisa dilihat dari dua sisi: (1) dari penulis sendiri, dan (2) dari orang lain. Sudut pandang penulis sendiri sebagai penulis, dianjurkan untuk menjunjung tinggi nilai kejujuran, dan keaslian sebuah karya. Normatifnya ialah, kalau bukan milik sendiri sudah seharusnya tidak dikatakan sebagai miliknya. Apabila kaidah normatif ini dilanggar, maka pelakunya telah melakukan perbuatan pengambilan hak milik (cipta) orang lain. Hal ini jelas termasuk perbuatan pidana. Dilihat dari sudut orang lain, pengambilan hak cipta milik orang lain jelas akan merugikan pihak lain secara ekonomis, moral, dan intelektual. Modus tindak plagiarisme karya tulis ilmiah pada umumnya terdiri atas: (1) mengcopy karya orang lain; (2) membonceng karya orang lain; (3) mengubah karya orang lain; (4) dibuatkan orang lain; dan (5) membeli karya orang lain. Modus seperti ini jelas telah menghancurkan nilai penghargaan atas hak cipta karya orang lain, dan lebih dari itu juga telah merendahkan nilai kejujuran dan derajat keilmiahan diri sendiri.

Hak cipta sebenarnya merupakan hak eksklusif bagi pencipta atau penerima hak untuk mengumumkan atau memperbanyak ciptaannya dalam bidang ilmu pengetahuan, seni dan sastra. Secara lengkap hak cipta ini meliputi:

- karya tulis : fiksi dan nonfiksi;

- karya musik: lagu, lirik, dan sebagainya;

- karya seni: tari, pantomim, koreografi, dan sebagainya;

- karya seni rupa: lukisan, karya cetak, patung, komik, kaligrafi, kerajinan, dan sebagainya;

- karya arsitektur: rancangan arsitektur, gambar gedung;

- karya foto: fotografi, gambar animasi, dan sebagainya;

- karya teknologi: program komputer, dan sebagainya.

Karya kategori lain yang mendapat perlindungan hukum mencakup ciptaan yang dihasilkan dengan menerjemahkan, mengaransemen, mengubah atau mengadaptasi karya orisinal (ciptaan turunan = derivative work), dan ciptaan yang telah diperiksa dan diperbaiki seperti ensiklopedi, kumpulan karya puisi, majalah, kompilasi koran (Panduan Hak Cipta Asia, Maris, 2006; Panduan HKI, 2006:9). 
Sebenarnya, aturan menyangkut sanksi bagi pelaku tindak plagiarisme sudah cukup jelas. Berdasarkan UU No.20/2003, tersebut bahwa sanksi atas tindak plagiarisme dalam persoalan karya tulis sebagai berikut.

- Lulusan PT yang karya ilmiahnya digunakan untuk memperoleh gelar akademik, profesi, atau vokasi, terbukti merupakan jiplakan, dicabut gelarnya ( $p a-$ sal 25 ayat 2).

- Lulusan yang tersebut pada pasal 25 ayat 2 dipidana dengan pidana penjara paling lama dua tahun, dan atau pidana denda paling banyak Rp. 200.000.000,(dua ratus juta rupiah). (Yasasan $\mathrm{Ru}-$ mah Ilmu Indonesia.E-Journal/2010/ 04/04).

Apapun hukum dan ketentuan menyangkut hak cipta dan pelanggarannya, apabila tidak diindahkan maka hasilnya hanya sia-sia belaka. Terus terang fakta menunjukkan, bahwa aturan formal tersebut tampaknya belum mampu menutup kasus-kasus menyangkut plagiarisme dalam karya tulis ilmiah. Azas etika universal belum dihargai secara maksimal (Zuchdi, 1994:9). Salah satu muara persoalan ialah: nilai kejujuran. Oleh karena itu, aspek inilah yang mestinya menjadi perhatian utama dalam proses character building (pembangunan jati diri dan watak) insan di dunia akademik.

\section{METODE}

Penelitian ini menggunakan pemecahan masalah dengan pendekatan proses yang dilakukan secara eksploratif, yaitu penelitian yang mengedepankan pengungkapan kasus-kasus yang terjadi dalam lingkup tertentu, dan dalam persoalan tertentu. Pengungkapannya dilakukan secara komprehensif, integratif, mendalam dan berkelanjutan. Model ini digunakan secara langsung karena dapat menyelesaikan masalah secara praktis. Waktu dan tempat penelitian dilakukan di Jurusan PBD FBS, sepanjang tahun 2008, tepatnya dimulai sejak bulan Mei Oktober 2008. Draf proposal tugas akhir skripsi yang masuk di jurusan didokumentasi dan diklasifikasi. Selanjutnya sejumlah persoalan yang muncul dicermati untuk kepentingan deskriptif-analitis. Subjek penelitian adalah draf proposal TAS, sementara objeknya adalah jenis-jenis duplikasi tugas akhir yang didindikasikan termasuk plagiarisme hak cipta karya tulis ilmiah. Topik-topik atau materi tugas akhir yang terindikasi plagiarisme dijadikan data penelitian untuk mendapatkan gambaran kasus-kasus apa saja yang melekat dalam persoalan ini.

Data dikumpulkan dengan teknik dokumentasi dan wawancara terbingkai. Artinya, data dikumpulkan dari sejumlah draf pengajuan tugas akhir yang masuk ke jurusan (data ini disimpan/didokumentasi dengan rapi oleh petugas administrasi jurusan, dan kemudian diserahkan kepada koordinator tim penyelesaian tugas akhir di Jurusan PBD FBS UNY). Wawancara juga dilakukan untuk menjaring sejumlah motif, dan gagasan mahaiswa tentang topik yang akan diajukannya. Data materi yang telah diklasifikasi sesuai dengan persoalan, kemudian dianalisis secara deskriptif kualitatif. Metode deskriptif digunakan untuk mengidentifikasi topik dan substansi tugas akhir yang di- 
ajukan mahasiswa. Langkahnya adalah menelaah seluruh data yang telah tersedia dari berbagai sumber, yaitu dari wawancara, observasi, catatan, dokumen, dan sejumlah sumber lainnya yang terkait. Sejumlah kemiripan karya yang berhasil ditemukan, selanjutnya dikenakan pendekatan dengan menggunakan teori Elliot (1990), yaitu: telaah, diagnosis, perencanaan, pelaksanaan, pemantauan, dan evaluasi. Pemeriksaan keabsahan data dilakukan dengan teknik triangulasi, yaitu pemeriksaan dari sejumlah sumber terkait untuk mendapat validitas dan reliabilitas data. Antara lain, dengan pemeriksaan sumber, wawancara, dan konsultasi antarahli (sesama dosen pembimbing) tugas akhir skripsi.

\section{HASIL DAN PEMBAHASAN}

Berdasarkan alur penelitian dan pendekatan proses yang telah dilakukan ditemukan sejumlah proposal atau karya skripsi yang dikembalikan dan atau dibatalkan karena alasan "mendekati plagiarisme". Artinya, beberapa proposal dan atau skripsi memiliki kemiripan atau duplikasi dalam hal judul, topik, data, dan kajian teori. Meskipun tidak termasuk dalam metode penelitian, namun berdasarkan pemantauan sebelumnya, kasus plagiarisme relatif memiliki kemiripan di beberapa jurusan lain di lingkungan FBS UNY, yaitu "duplikasi karya" atau peniruan karya tulis mahasiswa lain.

Duplikasi atau peniruan karya yang ditemukan di Jurusan PBD FBS UNY antara lain adalah: duplikasi judul, duplikasi substansi, duplikasi kajian teori, duplikasi data, dan duplikasi referensi. Sejumlah faktor yang menyebabkan terjadinya gejala plagiarisme tersebut antara lain adalah: (1) faktor internal (berkaitan dengan watak, karakter); (2) faktor eksternal (berkaitan dengan kondisi, kesempatan). Hasil penelitian tampak pada tabel 1 berikut.

Tabel 1. Jenis Plagiarisme TAS Mahasiswa

\begin{tabular}{lll}
\hline \multicolumn{1}{c}{ Kasus } & \multicolumn{1}{c}{ Jenis Plagiarisme } & \multicolumn{1}{c}{ Tindakan Pencegahan } \\
& 1. duplikasi judul & 1. Mengembalikan usulan TAS dan atau \\
& 2. duplikasi substansi & merevisi \\
Plagiarisme & 3. duplikasi teori & 2. Mengharuskan pengutipan sumber \\
Skripsi & 4. duplikasi data & primer \\
& 5. duplikasi referensi & 3. Membatalkan karya tulis \\
\hline
\end{tabular}

Plagiarisme berbentuk duplikasi judul. Duplikasi judul menyangkut kesamaan atau kemiripan judul. Sejumlah tugas akhir yang diajukan ke jurusan atau dikonsultasikan ke calon pembimbing terindikasi memiliki kesamaan, sehingga perlu segera diantisipasi. Misalnya:
- Kajian Register Dakwah Islam KH Ma'ruf Islamudin

- Pemakaian Bahasa Dakwah Islam KH Ma'ruf Islamudin

Duplikasi semacam ini tampak jelas hanya berbeda dalam hal pemilihan kosa kata. Yaitu antara "kajian register" dengan "pemakaianbahasa". Untuk mengantisipasi munculnya gejala plagiaris- 
me lebih lanjut, draf kedua atau yang terakhir diajukan dikembalikan kepada mahasiswa untuk diperbaiki atau diganti dengan judul atau topik lain. Tindak pencegahan dengan cara persuasif, yaitu "mengembalikan usulan" ditekankan dengan dua pilihan: ganti atau revisi. Pada tahap awal, mahasiswa akan segera menyadari kelalaiannya melakukan tindak duplikasi, yang kemungkinan dilakukan dengan sadar atau tidak.

Plagiarisme berbentuk duplikasi substsansi. Bentuk ini maksudnya adalah kesamaan atau kemiripan dalam hal isi dan substansi yang diteliti. Duplikasi isi, pada umumnya terjadi karena karya tersebut menggunakan objek kajian yang sama. Misalnya:

\section{- Nama-nama Dusun Di Kecamatan Kretek \\ - Nama-nama Dusun Di Kecamatan Kalasan}

Kesamaan secara substansial dapat dilihat dalam hal kajian "nama-nama dusun". Perbedaannya hanya terletak pada seting penelitian, dan spesifikasi kajian yang dilakukan. Duplikasi isi akan mengurangi orisinalitas peneliti dalam mengeksplorasi data penelitian. Artinya, peneliti tidak akan banyak bekerja karena sudah dituntun oleh penelitian terdahulu yang mirip.

Plagiarisme berbentuk duplikasi teori. Kasus ini tampaknya paling banyak ditemukan dalam penulisan tugas akhir mahasiswa Jurusan PBD FBS UNY. Sebagaimana sinyalemen yang dilakukan oleh Tim Percepatan TAS (lihat Nurhayati, 2006; Mulyani, 2006; dan Widyastuti, 2006), pengajuan TAS biasanya menunjukkan gejala musiman topik.
Misalnya, pada tahun ini, banyak mahasiswa yang menulis bidang sosiolinguistik, tahun berikutnya mayoritas menulis foklor, tahun berikutnya lagi, menulis kajian nilai-nilai moral, berikutnya juga ditemukan penelitian pengajaran yang hampir semuanya mengedepankan Penelitian Tindakan kelas (PTK), demikian seterusnya. Akibatnya, setiap musim (angkatan pengajuan tugas akhir), bentuk kajiannya menunjukkan gejala duplikasi teori. Sebagaimana diketahui, kajian teori yang umumnya ditulis pada BAB II (Panduan TAS FBS UNY, 2009) yang mengambil topik atau bidang penelitian yang sama, banyak yang menunjukkan kesamaan teori antara skripsi yang satu dengan lainnya. Kajian penelitian skripsi di Jurusan PBD dipilah menjadi empat bidang, yaitu bahasa, sastra-filologi, budaya, dan pengajaran(nya). Kajian dalam bidang dan spesialisasi yang sama, rentan terjadi duplikasi, misalnya:

- Penggunaan Bahasa Jawa Dialek Banyumas di lingkungan Kantor Pemerintahan Kebumen

- Register Politik di Kantor-kantor Pemerintahan Desa di Kabupaten Bantul

- Register SMS Mahasiswa Jurusan Pendidikan Bahasa Daerah FBS UNY. Sebuah Kajian Sosiolinguistik.

Kajian teori biasanya diletakkan di bagian kedua (Bab II) sesuai dengan format penulisan tugas akhir (PTA, 2006). Ketiga draf judul di atas semuanya bermuara pada bidang kajian sosiolinguistik. Data penelitian menunjukkan pada BAB II ketiga usulan penelitian tersebut nyaris sama. Kesamaan itu dimulai dengan penyusunan urutan teori: a) pengertian sosiolinguis- 
tik; b) variasi bahasa; dan c) register, dengan sejumlah subjudul yang duplikatif. Hal sama terjadi juga dalam bidang sastra (topik kajian gaya bahasa). Misalnya: a) Kajian Majas dan Gaya Bahasa Geguritan pada Antologi Cerkak lan Geguritan Yogyakarta, dengan skripsi lain yang berjudul; b) Pemakaian Diksi DAN Gaya Bahasa Pada Geguritan Karya $S E$. Bisa dipastikan kajian teori kedua skripsi tersebut sama (salah satu menjadi duplikasi lainnya). Kasus semacam ini dapat dicegah dengan upaya mewajibkan penulis TAS menyebutkan, menyertakan, dan kalau perlu membawa secara fisik sumber primer kutipannya.

Sementara itu, plagiarisme berbentuk duplikasi referensi. Sering ditemukan pada bagian daftar pustaka (referensi). Terbukti bahwa mahasiswa hanya mengcopi daftar pustaka skripsi lain yang memiliki kesamaan substansi. Bukti bahwa mahasiswa melakukan duplikasi referensi karena mereka pada umumnya tidak menemukan dan membaca sendiri pustaka yang dicantumkan pada bagian daftar pustaka skripsinya. Pada bagian lain, persoalan kutip-mengutip referensi ini bahkan juga tejadi gejala penyandaran referensi palsu. Bentuk ini cukup meresahkan dunia akademik, karena mahasiswa menuliskan sebuah sumber (ide, gagasan, pendapat, lainnya), sebagai milik orang lain, tetapi ternyata miliknya sendiri. Atau bahkan sebaliknya, dan ini yang paling berbahaya, mahasiswa menulis atau mengutip sebuah referensi (baik sedikit maupun banyak) tanpa menyertakan dari mana sumbernya. Inilah yang disebut plagiarisme karya tulis. Upaya pencegahan yang dilakukan adalah "membatalkan TAS"-nya. Solusinya: "merevisi substansi secara total, atau membatalkan atau mengganti karyanya dengan topik lain". Inilah upaya paling berat yang dilakukan untuk mengantisipasi terjadinya tindak plagiarisme TAS.

Berdasarkan diagnosis penelitian yang berupa pantauan dan perlakukan penelitian yang diterapkan, ditemukan sejumlah hambatan yang dialami mahasiswa dalam mengajukan dan menulis TAS (skripsi). Secara umum, hambatan yang menjadi faktor penyebab terjadinya bentuk plagiarisme tugas akhir adalah: faktor internal dan eksternal. Kedua faktor itu dapat diuraikan menjadi beberapa faktor, yaitu: (1) motivasi rendah; (2) kurang memahami materi yang ditulisnya sendiri; (3) kemampuan menulis rendah; (4) kurang komunikasi dengan pembimbing; (5) ingin cepat selesai dan mencari jalan pintas; dan (6) persoalan pribadi mahasiswa.

Sejumlah hambatan di atas, tampaknya terakumulasi menjadi satu hambatan besar yang dialami mahasiswa sejak awal mengajukan proposal skripsi. Akibatnya, topik yang diajukan mahasiswa terkesan 'asal jadi', 'cari yang gampang' dan 'pokoknya mengajukan'. Tim koordinasi penyelesaian tugas akhir Jurusan PBD sudah menginventarisasi hambatan dan bagaimana solusinya.

Hambatan internal bermuara pada kurangnya semangat dan motivasi mahasiswa untuk menulis tugas akhir dengan mutu yang memadai. Akibatnya apa yang ditulis atau diajukan hanya asal mengajukan. Cara untuk mengatasinya adalah dengan menum- 
buhkan semangat dan kemampuan mahasiswa, sambil terus menerus meyakinkan bahwa mahasiswa sebenarnya mampu menulis dengan tingkat orisinalitas yang tinggi dan mutu yang mamadai. Sementara itu, hambatan atau aspek yang bersifat teknis, misalnya kurangnya kemampuan di bidang kebahasaan (misalnya, keterampilan menyusun kalimat, paragraf) dapat diantisipasi dengan banyak latihan menulis, membaca karya penelitian lain, dan memahami benar panduan penulisan tugas akhir. Hambatan eksternal lain, semacam kesibukan berorganisasi, bekerja, dan kurangnya komunikasi dengan pembimbing bisa diatasi dengan pendekatan personal, pembuatan jadwal waktu secara ketat dan mengerjakan tugas penulisan secara proporsional. Selanjutnya, plagiarisme dalam penulisan TAS/TABS terutama di jurusan PBD FBS dapat dikurangi dengan langkah-langkah sesuai dengan pendekatan proses sebagaimana telah diuraikan pada tahap penemuan gejala plagiarisme tugas akhir yang ditulis mahasiswa. Penanganan minimal yang dapat dilakukan adalah:

- mendidentifikasi gejala duplikasi tugas akhir;

- membahas gejala duplikasi tersebut dengan anggota tim TAS/TABS Jurusan;

- membicarakan gejala duplikasi tersebut dengan mahasiswa bersangkutan;

- mengembalikan darf proposal dengan menunjukkan kemiripannya dengan karya lain yang sudah ada sebelumnya; dan
- pada tindakan selanjutnya, mahasiswa harus memperbaiki draf dan atau mengganti karya tulisnya agar tidak terkena sanksi akademis yang menjadi kebijakan institusi.

Tahapan solusi dan pencegahan tindak plagiarisme dalam penelitian ini baru pada tingkat antisipasi. Penerapan pendekatan proses bertujuan melatih mahasiswa memahami gejala plagiarisme dan selanjutnya menjauhi segala bentuk plagiarisme dalam karya tulis ilmiahnya. Terus terang, inti persoalannya kadang-kadang tidak atau belum mampu ditangani secara teknis administratif. Plagiarisme hampir pasti menyangkut aspek moral seseorang. Oleh karena itu, penanganan dalam penelitian ini untuk sementara hanya bersifat pembinaan dan pencegahan.

\section{KESIMPULAN}

Gejala plagiarisme tugas akhir yang dilakukan mahasiswa Jurusan PBD FBS UNY pada umumnya masih pada taraf duplikasi, yaitu bentuk-bentuk peniruan, penjiplakan karya orang lain dengan persentase duplikasi yang bervariasi (ada yang sedikit ada yang cukup dominan). Pendekatan proses yang dilakukan dalam penulisan tugas akhir berhasil mengidentifikasi sejumlah jenis plagiarisme dan mempublikasikan solusi terbaik untuk mengantisipasi tindakan negatif tersebut. Sejumlah jenis plagiarisme karya tulis tersebut antara lain adalah: a) duplikasi judul; b) duplikasi substansi; c) duplikasi kajian teori; d) duplikasi data/objek; e) penyandaran referensi palsu, dan atau duplikasi referensi. 
Tindak plagiarisme yang berbentuk duplikasi menunjukkan kesadaran mahasiswa untuk menjunjung nilai orisinalitas masih rendah. Semangat yang berkembang dalam kasus ini berkutat pada keinginan agar lebih mudah, lebih cepat, dan tidak mau terlalu sulit dalam menyelesaikan tugas akhirnya. Di samping itu, duplikasi belum dianggap sebagai tindakan negatif yang perlu dihindari oleh semua orang. Upaya penekanan dan pencegahan tindak plagiarisme skripsi merupakan salah satu pengembangan ke arah character building di dunia akademik yang sangat penting. Upaya pencegahan tindak plagiarisme TAS antara lain adalah mengembalikan usulan, menyertakan referensi primer, dan merevisi total dan atau mengganti karya tulis tersebut. Pendekatan proses yang dilakukan telah berhasil menyodorkan solusi agar gejala plagiarisme tugas akhir tidak berkembang. Penyelesaiannya juga bertahap, yaitu: (1) mendidentifikasi gejala duplikasi tugas akhir; (2) membahas gejala duplikasi tersebut dengan anggota tim TAS/ГABS Jurusan; (3) membicarakan gejala duplikasi tersebut dengan mahasiswa bersangkutan; (4) mengembalikan proposal dengan menunjukkan kemiripannya dengan karya tulis lain; (5) pada tindakan selanjutnya, mahasiswa harus memperbaiki dan atau mengganti skripsinya.

\section{UCAPAN TERIMA KASIH}

Penelitian ini dapat berlangsung dengan relatif lancar, karena adanya sejumlah bantuan dari beberapa pihak. Oleh karena itu, dalam kesempatan ini peneliti ingin menyampaikan rasa te- rimakasih yang setulusnya kepada pihak-pihak: staf perpustakaan FBS UNY yang sangat membantu jalannya penelitian, staf administrasi Jurusan yang terus menerus menyiapkan data dan katalog skripsi jurusan. Juga pihak DP2M Dikti sebagai pemberi dana penelitian. Terakhir, kepada para mahasiswa dan siapa saja yang terlibat dalam proses penelitian ini mulai awal sampai selesai. Semoga karya penelitian ini bermanfaat.

\section{DAFTAR PUSTAKA}

Astin, Alexander. 1993. Assesment for Excellent: The Phylosophy and Practice of Assesment and Excellence in Higher Education. USA: The Oryx Press.

FBS UNY, 2006. Panduan Tugas Akhir. Yogyakarta: Fakultas Bahasa dan Seni.

http://edukasi.kompasiana.com/2010/04 16/gunung es plagiarisme.

http:/ðurnal-blogspot.com/2010/04/04.yayasan rumah ilmu indonesia.ejournal.

Ismail, Taufiq, "Pencucian Citra SDM Warisan Kolonial, Peletakan Paradigma SDM Baru; Mungkinkah? Yogyakarta: Naskah Pidato Dies Natalis UNY, 2006.

Jurusan PBD FBS UNY. 2006. Laporan Lokakarya Percepatan Tugas Akhir. Yogyakarta. 
Moeliono, Anton M. Ed. 2001. Kamus Besar Bahasa Indonesia. Jakarta: PT Gramedia.

Mashoedah, 2008. Pengenalan HKI (Hak Kekayaan Intelekatual). Sentra HKI Lemlit UNY.

Mulyani, Siti. 2006. "Kiat Mengatasi Kendala Penulisan TAS". Makalah Percepatan Tugas Akhir (PTA).

Nurhayati, Endang. 2006. “Fakus Kajian Bidang Kebahasaan pada Penulisan TAS". Makalah Percepatan Tugas Akhir.

Fakultas Bahasa dan Seni. 2006. Panduan Tugas Akhir. FBS UNY

Universitas Negeri Yogyakarta. 2005. Peraturan Akademik UNY.

Rachmad, Edy. 2010. "Fenomena Plagiarisme di Kampus". Jurnal Waspada Medan.
Sudaryanto. 2000. “Upaya Meningkatkan Keterampilan Menulis Wacana Siswa SMP di Yogyakarta dengan Pendekatan Proses". Laporan Penelitian Proyek PGSM Depdiknas.

Suyanto. "Tantangan Profesional Guru di Era Global". Pidato Dies Natalis UNY ke 43. 21 Mei 2007.

Suyata. 1998. "Perbaikan Mutu Pendidikan Transformasi Sekolah dan Implikasi Kebijakan". Naskah Pidato Dies Natalis XXXIV IKIP Yogyakarta.

TVOne. 2010. Running News. 18 April.

Widyastuti, Sri Harti. 2006. "Penulisan TAS Bidang sastra". Makalah PTA.

Zuchdi, Darmiyati. 1994. "Antisipasi Pelaksanaan Wajib Belajar Pendidikan Dasar Sembilan Tahun Berpijak pada Wawasan Budaya". Pidato Ilmiah Lustrum VI IKIP Yogyakarta. 